J. Product. \& Dev., 16(2):223 - 246(2011)

\title{
GROWTH, PRODUCTIVITY AND SULPHUR USE EFFICIENCY OF GARLIC PLANTS GROWN IN SANDY SOIL AS AFFECTED BY FARMYARD MANURE AND SULPHUR
}

\author{
A. Bardisi, H. E.M. Ismail and Dalia, A. S. Nawar \\ Hort. Department, Faculty of Agriculture, Zagazig University, Egypt.
}

\begin{abstract}
This experiment was carried out during two successive winter seasons of 2008/2009 and 2009/2010 at EL-Khattara Experimental Farm, Faculty of Agriculture, Zagazig University, Sharkia Governorate, to study the effect of farmyard manure (FYM), elemental sulphur $(S)$ and their interactions on growth, plant chemical composition and yield and its components as well as sulphur use efficiency (SUE) of garlic plants under sandy soil conditions.

Addition of $30 \mathrm{~m}^{3} \mathrm{FYM} / \mathrm{fed}$. recorded maximum values of total dry weight / plant, chlorophyll $a, b$ and total chlorophyll $(a+b), N, P$ and $K$ uptakes by different plant organs and total uptake by plant, yields of grades 1 and 2, exportable, marketable and total yield/fed. as well as average bulb weight of garlic plants.

Obtained results indicated that application of $S$ at the rate of 200 $\mathrm{kg} / \mathrm{fed}$. recorded maximum values of dry weight of roots, bulb, leaves and total / plant, total uptake of N, $P$ and K by plant, yields of grades 1, 2 exportable, marketable and total yield/fed as well as average bulb weight of garlic plants, whereas $S$ at $100 \mathrm{Kg} / f e d$ increased chlorophyll $a, b$ and total $(a+b)$ in leaf tissues and sulfur use efficiency.

The interaction between FYM at the rate of $30 \mathrm{~m}^{3} / \mathrm{fed} .200 \mathrm{~kg}$ S/fed. significantly increased total dry weight / plant , $P$ content in roots, $N$ and $P$ in bulb and N,P and $K$ contents in leaves, uptakes of $N, P$ and $K$ by roots, bulb and leaves as well as total uptakes of N,P and $K$ by plant, yields of grades 1,2 and 3, exportable, marketable and total yield/fed., as well as, average bulb weight, whereas the interaction between FYM at $20 \mathrm{m3} / \mathrm{fed}$ and $\mathrm{S}$ at $100 \mathrm{Kg} / \mathrm{fed}$ increased sulpher use efficiency.
\end{abstract}

Key words: Garlic, FYM, S, dry weight, leaf pigments, mineral uptake, yield, components, sulphur use efficiency.

\section{INTRODUCTION}

Garlic (Allium sativum L.) is one of the most important bulb vegetable crops and is next to onion in importance. It is commonly used as a spice or in 
many medicinal purposes. In Egypt, it has been generally cultivated for both local consumption and export. Therefore, increasing garlic yield and improving bulb quality are essential aims for both growers and consumers, but that advances usually depends on many factors especially that influence the plant growth throughout the growth period.

Farmyard manure is one of the traditional organic manures and is most readily available to the farmers. Farmyard manure seems to act directly in increasing crop yields by supplying nitrogen, phosphorus and sulphur in available forms to the plant through biological decomposition. Moreover, it improve physical properties of soil such as aggregation, aeration, permeability and water holding capacity. Also, it helps to increase the productivity of the soil by improving chemical properties viz., soil organic carbon content, increase the availability of both major and minor nutrients and availability of nutrients for longer period, biological properties increased decomposition rate. The organic matter content of the Egyptian soil is usually less than $2 \%$ in cultivated area. Frequent and high applications of organic manure are necessary to maintain soil fertility. Farmyard manure is usually used as the main organic fertilizer in Egypt (Abdel -Moez et al., 1999).

Fertilization of garlic plants with farmyard manure increased total dry weight /plant, $\mathrm{N}$ and $\mathrm{P}$ uptakes by leaves and $\mathrm{N}, \mathrm{P}$ and $\mathrm{K}$ uptakes by bulb (Khalaf and Taha, 1988; Ali et al., 2001, Shafeek et al. , 2003; El-Mansi et al., 2004a, on garlic). Increasing organic manure increased yield and its components of garlic (Seno et al.,1996 ; Fayed, 1998; Zhang, 1998; Ali et al.,2001; El-Mansi et al., $2004 \mathrm{~b}$ and El-Hifny, 2010).

The role of sulphur application as a soil amendment and as a factor of increasing fertilizer efficiency is very important. Application of sulphur to soil has several effects such as reducing $\mathrm{pH}$, improving soil water relation and increasing availability of nutrients like P, Fe, Mn and Zn (Marschner, 1998). Moreover, secondary compounds (allin, cycloallin and thiopropanol) which contained sulphur are not only important for nutritive value or flavours but also for resistance against pest and diseases (Brown and Morra, 1997). Sulphur as a macronutrient has a positive effect on garlic and other crops (Bloem et al., 2004).

In this regard, Khalaf and Taha (1988), Singh et al. (1995), Abd ElHameed (1997), Mee et al. (1997), El-Morsy (2005), Losak and WiniowskaKielian (2006), Mansour (2006), Farooqui et al. (2009) and Abou El-khair (2010) found that sulphur fertilization enhanced garlic plant dry weight, N, P and $\mathrm{K}$ contents in different plant organs of garlic and yield and its components.

Therefore, the main objectives of present investigation to study the effect of farmyard manure under different rates of elemental sulphur to reach the best one to have the perfect beneficial towards better growth, yield and its components, of garlic bulbs (Balady cv.) under sandy soil conditions. 


\section{MATERIALS AND METHODS}

This experiment was carried out during two successive winter seasons of 2008/2009and 2009/2010 at EL-Khattara Experimental Farm, Faculty of Agriculture, Zagazig University, Sharkia Governorate, to study the effect of farmyard manure, elemental sulphur and their interactions on growth, plant chemical composition and yield and its components as well as sulphur use efficiency of garlic plants under sandy soil conditions.

The physical and chemical analysis of the experimental soil and farmyard manure are presented in Tables $1 a$ and $b$.

Table 1a: The physical and chemical properties of the experimental soil in 2008/2009 and 2009/2010 seasons

\begin{tabular}{l|cc}
\hline Soil property & $\mathbf{1}^{\text {st }}$ Season & $\mathbf{2}^{\text {nd }}$ Season \\
\hline Physical properties & & \\
Sand (\%) & 90.84 & 91.33 \\
Silt (\%) & 5.16 & 2.23 \\
Clay (\%) & 3.94 & 6.40 \\
Organic matter (\%) & 0.07 & 0.05 \\
Texture & Sandy & Sandy \\
Chemical properties & & \\
pH & 8.27 & 8.21 \\
E.C. (mmhos/cm) & 2.01 & 2.11 \\
Available N (ppm) & 4.27 & 3.83 \\
Available P (ppm) & 4.43 & 4.12 \\
Available K (ppm) & 11.32 & 10.46 \\
\hline \multicolumn{2}{l}{ Samples }
\end{tabular}

Samples of the soil were obtained from $25 \mathrm{~cm}$ soil surface.

Table 1b: Analysis of farmyard manure

\begin{tabular}{l|cc}
\hline Properties & $\mathbf{1}^{\text {st }}$ Season & $\mathbf{2}^{\text {nd }}$ Season \\
\hline Total N \% & 0.49 & 0.48 \\
Total N units in $\mathrm{m}^{3}(328 \mathrm{~kg})$ & 1.607 & 1.574 \\
\hline
\end{tabular}

This experiment included nine treatments, which were the combinations between three farmyard manure rates; i.e., 10,20 and $30 \mathrm{~m}^{3}$ /fed. and three rates of elemental sulphur; i.e., 0, 100 and $200 \mathrm{~kg} /$ feddan.

These treatments were arranged in a split plots in a complete randomized block design with three replications. The FYM treatments were randomly arranged in the main plots and the rates of sulphur were randomly distributed in the sub plots.

Plot size was $12.6 \mathrm{~m}^{2}$.It contained three dripper lines with $7 \mathrm{~m}$ long and $60 \mathrm{~cm}$ in wide. Garlic cloves of Balady $c v$ were selected for uniformity 
in shape and size. The cloves were sown on both sides of the dripper lines on September $20^{\text {th }}$ in both seasons at $10 \mathrm{~cm}$ apart.

All experimental units received equal amounts of commercial fertilizers; i.e., 120, 100 and $100 \mathrm{~kg}$ / fed. N, P and K fertilizers in the form of ammonium sulfate $(20.6 \% \mathrm{~N})$, calcium superphosphate $\left(15.5 \% \mathrm{P}_{2} \mathrm{O}_{5}\right)$ and potassium sulfate $\left(48 \%-52 \% \mathrm{~K}_{2} \mathrm{O}\right)$, respectively.

Total amounts of FYM, elemental sulphur and one third of the commercial fertilizers of $\mathrm{N}, \mathrm{P}$ and $\mathrm{K}$ were added at soil preparation. The rest of commercial fertilizers (two thirds) were added monthly at three portions as soil application beginning one month after sowing. The other normal agricultural treatments for growing garlic plants were practiced.

\section{Data Recorded}

\section{Growth Parameters}

A random sample of ten plants was taken from each plot at 135 days after sowing in both seasons of study, for measuring the growth characters of garlic plants; i.e., plant height $(\mathrm{cm})$, leaf number /plant, neck diameter $(\mathrm{mm})$, bulb diameter $(\mathrm{mm})$, and bulbing ratio.

The different parts of garlic plant; i. e., roots, leaves and bulb were oven dried at $70{ }^{\circ} \mathrm{C}$ till constant weight and then the following data were recorded.

Root dry weight /plant, bulb dry weight /plant, leaf dry weight /plant, and total dry weight (roots + bulb +leaves) /plant (g).

\section{Photosynthetic pigments}

Chlorophyll (a \& b), as well as, carotenoids in leaf tissues $(\mathrm{mg} / \mathrm{gm}$ dry weight) were determined at 135 days after sowing according to the method described by Wettestein (1957).

\section{Nitrogen, Phosphorus and Potassium Contents:}

They were determined in roots, bulb and leaves on the basis of dry weight according to the methods described by Bremner and Mulvaney (1982), Olsen and Sommers (1982) and Jakson (1970), respectively. N, P and $\mathrm{K}$ uptakes and total uptake were calculated.

\section{Yield and Its Components}

At proper maturity stage of bulbs (200 days after sowing), bulbs of every plot were harvested and graded into four categories according to specification laid down by the Ministry of Economic for garlic exportation (1963) as follows:

Grade 1: Bulbs with diameter above $5.5 \mathrm{~cm}$,

Grade 2: Bulbs with diameter between $4.5-5.5 \mathrm{~cm}$,

Grade 3: Bulbs with diameter between 3.5-4.4 cm, and

Grade 4: Bulbs with diameter less than $3.5 \mathrm{~cm}$. 
After that, each grade was weighed separately in the same day and the following data were recorded:

1.Exportable yield (grade $1+$ grade 2 ) ton /fed,

2.Marketable yield (grade $1+$ grade $2+$ grade 3 ) ton/fed, and

3.Total yield (grade $1+$ grade $2+$ grade $3+$ grade 4 ) ton/fed.

\section{Average bulb fresh weight}

Yield of bulbs /plot

\section{Sulphur Use Efficiency (SUE):}

Total number of bulbs/plot

It was calculated according to equation of Bharathi and Poongothai (2008) as follows:

$\mathrm{SUE}=($ Yield of $\mathrm{S}$ applied- yield of control $) / \mathrm{S}(\mathrm{kg} / \mathrm{fed})=$. yield $(\mathrm{kg} / \mathrm{kg} \mathrm{S})$

\section{Statistical Analysis}

All obtained data were subjected to the analysis of variance according to Snedecor and Cochran (1980). Mean separation was done according to LSD at $5 \%$ level.

\section{RESULTS AND DISCUSSION}

\section{Plant Growth}

\subsection{Effect of farmyard manure (FYM)}

Fertilization of garlic plants grown in sandy soil with farmyard manure (FYM) at $30 \mathrm{~m}^{3} / \mathrm{fed}$. significantly increased plant height, number of leaves/ plant, neck and bulb diameter, bulbing ratio, dry weight of roots, bulb, leaves and total dry weight/ plant, except number of leaves/ plant and dry weight of leaves in the $1^{\text {st }}$ season and bulbing ratio in the $2^{\text {nd }}$ season (Tables 2 and 3). The increases in total dry weight were about 7.12 and $8.77 \%$ for FYM at $20 \mathrm{~m}^{3} /$ fed. and 15.22 and $26.41 \%$ for FYM at 30 $\mathrm{m}^{3} /$ fed. over the FYM at $10 \mathrm{~m}^{3} / \mathrm{fed}$ in the $1^{\text {st }}$ and $2^{\text {nd }}$ seasons, respectively. Since sandy soil had low organic matter and also low mineral content ( Table 1a), farmyard manure can improve its content of organic matter and this in turn led to improve soil conditions. For maximization exploitation of organic matter, mineralization of the manure by its flora needs of $\mathrm{N}$ supply induced multiplication of such flora to utilize the organic manure. Therefore, application of organic and mineral nitrogen fertilizers together may increase the exchangeable NPK and the uptake of these elements as found by Cooke (1972) which consequently led to increase cell division and cell enlargement and as a result this might be reflected on the plant growth. 
Table 3: Effect of farmyard manure and sulphur quantity on dry weight of different garlic organs at 135 days after planting during 2008/2009 and 2009/2010 seasons under sandy soil conditions

\begin{tabular}{|c|c|c|c|c|c|c|c|c|}
\hline \multirow{3}{*}{ Treatments } & \multicolumn{8}{|c|}{ Dry weight ( g/organ) } \\
\hline & \multicolumn{2}{|c|}{ Root } & \multicolumn{2}{|c|}{ Bulb } & \multicolumn{2}{|c|}{ Leaves } & \multicolumn{2}{|c|}{$\begin{array}{c}\text { Total dry } \\
\text { weight }\end{array}$} \\
\hline & $1^{\text {st }}$ & $2^{\text {nd }}$ & $1^{\text {st }}$ & $2^{\text {nd }}$ & $1^{\text {st }}$ & $2^{\text {nd }}$ & $\mathbf{1}^{\text {st }}$ & $2^{\text {nd }}$ \\
\hline & \multicolumn{8}{|c|}{ Effect of FYM $\left(\mathrm{m}^{3} /\right.$ fed. $)$} \\
\hline 10 & 1.21 & 0.93 & 3.95 & 3.93 & 5.21 & 5.05 & 10.38 & 9.92 \\
\hline 20 & 1.31 & 1.20 & 4.47 & 4.24 & 5.33 & 5.34 & 11.12 & 10.79 \\
\hline 30 & 1.43 & 1.69 & 4.88 & 4.83 & 5.64 & 6.01 & 11.96 & 12.54 \\
\hline \multirow[t]{2}{*}{ LSD at 0.05 level } & 0.09 & $\mathbf{0 . 3 5}$ & 0.58 & 0.51 & NS & 0.73 & 0.82 & 0.66 \\
\hline & \multicolumn{8}{|c|}{ Effect of sulphur (kg/fed.) } \\
\hline $\mathbf{0}$ & 1.24 & 1.04 & 4.33 & 3.92 & 5.23 & 5.12 & 10.81 & 10.09 \\
\hline 100 & 1.32 & 1.26 & 4.36 & 4.34 & 5.43 & 5.46 & 11.11 & 11.07 \\
\hline 200 & 1.38 & 1.52 & 4.62 & 4.74 & 5.53 & 5.82 & 11.54 & 12.09 \\
\hline LSD at 0.05 level & NS & 0.10 & NS & 0.18 & 0.14 & 0.30 & 0.47 & 0.44 \\
\hline
\end{tabular}

FYM: Farmyard manure, $1^{\text {st }}$ and $2^{\text {nd }}$ : First and second seasons, respectively

These results are in harmony with those obtained by Fayed (1998), Farrag and Hussein (2000), Ali et al. (2001), Shafeek et al. (2003), El-Mansi et al. (2004a) and El-Hifny (2010) all on garlic. They found that organic manure significantly increased all plant growth parameters; i.e., plant height, number of leaves/plant, fresh and dry weights of bulb, as well as, bulb and neck diameter and bulbing ratio.

\subsection{Effect of sulphur (S)}

The obtained results in Tables 2 and 3 show that fertilization of garlic plants with sulphur (S) at $200 \mathrm{~kg} / \mathrm{fed}$. significantly increased plant height, number of leaves/ plant, neck and bulb diameter, dry weight of roots, bulb, leaves and total dry weight/ plant, but had insignificant effect on number of leaves/ plant and dry weight of roots in the 1 st season and bulbing ratio in both seasons. The increases in total dry weight were about 2.97 and $9.7 \%$ for $\mathrm{S}$ at $100 \mathrm{~kg} / \mathrm{fed}$. and 6.75 and $19.02 \%$ for $S$ at $200 \mathrm{~kg} /$ fed. over the control (without $S$ ) in the 1st and 2nd seasons, respectively.

Overall increases in growth attributes may be due to that sulphur increased root system growth which in turn enhanced nutrients uptake and the other dependent physiological processes like photosynthesis (Jaggi, 2004). 
These results coincided with those reported by Khalaf and Taha (1988), Singh et al. (1995), Mee et al. (1997), El-Morsy (2005), Losak and WiniowskaKielian (2006) and Farooqui et al. (2009) and Abou El-Khair (2010). They found that sulphur fertilization enhanced growth of garlic; i.e., vegetative growth and dry weight / plant.

\subsection{Effect of the interaction between FYM and $S$}

It is clear from data in Tables 4 and 5 that the interaction between fertilization with FYM at $20 \mathrm{~m}^{3} / \mathrm{fed}$. and $\mathrm{S}$ at $200 \mathrm{~kg} / \mathrm{fed}$. and the interaction between FYM at $30 \mathrm{~m} 3 / \mathrm{fed}$. and $\mathrm{S}$ at $200 \mathrm{~kg} / \mathrm{fed}$. recorded the tallest plants in both seasons, whereas the interactions between FYM at $30 \mathrm{~m}^{3} / \mathrm{fed}$. and $\mathrm{S}$ at 100 or $200 \mathrm{~kg} / \mathrm{fed}$ recorded the maximum values of neck diameter in both seasons.

The interaction between FYM at $30 \mathrm{~m}^{3} / \mathrm{fed}$. and $\mathrm{S}$ at $200 \mathrm{~kg} / \mathrm{fed}$. gave the highest values of number of leaves/ plant, bulb diameter, dry weight of root, bulb, leaves and total dry weight/ plant, followed by the interaction between FYM at $30 \mathrm{~m}^{3} / \mathrm{fed}$ and $\mathrm{S}$ at $100 \mathrm{~kg} / \mathrm{fed}$., except number of leaves and root dry weight in the 1st season and bulbing ratio in both seasons. The increases in total dry weight were about 15.81 and $32.69 \%$ for the interaction between FYM at 30 $\mathrm{m}^{3} / \mathrm{fed}$. and $\mathrm{S}$ at $100 \mathrm{~kg} / \mathrm{fed}$, , 26.38 and $50.03 \%$ for the interaction between FYM at $30 \mathrm{~m}^{3} / \mathrm{fed}$. and $\mathrm{S}$ at $200 \mathrm{~kg} / \mathrm{fed}$. over the interaction between FYM at 10 $\mathrm{m}^{3} /$ fed. and control (without $\mathrm{S}$ ) in the $1 \mathrm{st}$ and 2 nd seasons, respectively.

\section{Photosynthetic pigments:}

\subsection{Effect of FYM}

Presented data in Table 6 show that the concentration of chlorophyll $\mathrm{a}, \mathrm{b}$ and total $(\mathrm{a}+\mathrm{b})$ as well as carotenoides in leaf tissues of garlic significantly increased with increasing FYM up to $30 \mathrm{~m}^{3} / \mathrm{fed}$. with no significant differences with FYM at $20 \mathrm{~m}^{3} / \mathrm{fed}$. with respect to chlorophyll b and total $(a+b)$ in the $2^{\text {nd }}$ season only. Application of FYM led to increase soil acidity, organic matter, available $\mathrm{P}$, exchangeable $\mathrm{Mn}$, and $\mathrm{Zn}$ and this in turn may affect leaf pigments (Hsieh and Hsu ,1993).

Results are in harmony with those obtained by El-Mansi et al. (2004a) they indicated that addition of $45 \mathrm{~m} 3 \mathrm{FYM} / \mathrm{fed}$. recorded maximum concentration of all leaf pigments in leaf tissues of garlic.

\subsection{Effect of sulphur}

The obtained results in Table 6 show that fertilization of garlic with $\mathrm{S}$ at 100 or $200 \mathrm{~kg} / \mathrm{fed}$. significantly increased chlorophyll $\mathrm{a}, \mathrm{b}$ and total $(\mathrm{a}+\mathrm{b})$ in the 1 st season and carotenoides in the $2^{\text {nd }}$ season, whereas $\mathrm{S}$ at $100 \mathrm{~kg} / \mathrm{fed}$. significantly increased total chlorophyll $(\mathrm{a}+\mathrm{b})$ in the 2 nd season only. 
Table 5: Effect of the interaction between farmyard manure and sulphur quantity on dry weight of different garlic organs at 135 days after planting during 2008/2009 and 2009/2010 seasons under sandy soil conditions

\begin{tabular}{|c|c|c|c|c|c|c|c|c|c|}
\hline \multirow{2}{*}{\multicolumn{2}{|c|}{ Treatments }} & \multicolumn{8}{|c|}{ Dry weight ( g/organ) } \\
\hline & & \multicolumn{2}{|c|}{ Root } & \multicolumn{2}{|c|}{ Bulb } & \multicolumn{2}{|c|}{ Leaves } & \multicolumn{2}{|c|}{$\begin{array}{c}\text { Total } \\
\text { dry weight }\end{array}$} \\
\hline FYM & Suphur & $1^{\text {st }}$ & $2^{\text {nd }}$ & $1^{\text {st }}$ & $2^{\text {nd }}$ & $1^{\text {st }}$ & $2^{\text {nd }}$ & $1^{\text {st }}$ & $2^{\text {nd }}$ \\
\hline \multirow[t]{3}{*}{10} & $\mathbf{0}$ & 1.18 & 0.72 & 3.70 & 3.65 & 5.05 & 4.83 & 9.93 & 9.20 \\
\hline & 100 & 1.20 & 1.02 & 4.04 & 3.85 & 5.28 & 5.05 & 10.53 & 9.92 \\
\hline & 200 & 1.25 & 1.07 & 4.12 & 4.30 & 5.31 & 5.27 & 10.69 & 10.64 \\
\hline \multirow[t]{3}{*}{20} & $\mathbf{0}$ & 1.24 & 1.00 & 4.28 & 3.73 & 5.13 & 4.87 & 10.66 & 9.61 \\
\hline & 100 & 1.31 & 1.23 & 4.57 & 4.35 & 5.41 & 5.41 & 11.30 & 11.00 \\
\hline & 200 & 1.37 & 1.37 & 4.55 & 4.65 & 5.46 & 5.75 & 11.39 & 11.78 \\
\hline \multirow[t]{3}{*}{30} & $\mathbf{0}$ & 1.31 & 1.40 & 5.00 & 4.39 & 5.52 & 5.68 & 11.85 & 11.48 \\
\hline & 100 & 1.44 & 1.53 & 4.46 & 4.83 & 5.58 & 5.94 & 11.50 & 12.30 \\
\hline & 200 & 1.53 & 2.14 & 5.19 & 5.27 & 5.82 & 6.43 & 12.55 & 13.84 \\
\hline \multicolumn{2}{|c|}{ LSD at 0.05 level } & NS & 0.18 & 0.73 & 0.30 & 0.24 & 0.52 & 0.82 & 0.77 \\
\hline
\end{tabular}

Table 6: Effect of farmyard manure and sulphur quantity on leaf pigments of garlic leaves at 135 days after planting, during $2008 / 2009$ and $2009 / 2010$ seasons under sandy soil conditions

\begin{tabular}{|c|c|c|c|c|c|c|c|c|}
\hline \multirow{3}{*}{ Treatments } & \multicolumn{8}{|c|}{ Leaf pigments ( mg/ gm DW) } \\
\hline & \multicolumn{2}{|c|}{$\begin{array}{l}\text { Chlorophyll } \\
\text { (a) }\end{array}$} & \multicolumn{2}{|c|}{$\begin{array}{l}\text { Chlorophyll } \\
\text { (b) }\end{array}$} & \multicolumn{2}{|c|}{$\begin{array}{c}\text { Total chlorophyll } \\
(\mathbf{a}+\mathbf{b})\end{array}$} & \multicolumn{2}{|c|}{ Carotenoides } \\
\hline & $1^{\text {st }}$ & $2^{\text {nd }}$ & $1^{\text {st }}$ & $2^{\text {nd }}$ & $1^{\text {st }}$ & $2^{\text {nd }}$ & $1^{\text {st }}$ & $2^{\text {nd }}$ \\
\hline & \multicolumn{8}{|c|}{ Effect of FYM $\left(\mathrm{m}^{3} / f e d.\right)$} \\
\hline 10 & 2.40 & 2.43 & 1.17 & 1.24 & 3.58 & 3.68 & 2.29 & 2.30 \\
\hline 20 & 2.55 & 2.70 & 1.44 & 1.27 & 4.00 & 3.97 & 2.49 & 2.51 \\
\hline 30 & 2.96 & 2.91 & 1.71 & 1.58 & 4.68 & 4.50 & 2.70 & 2.83 \\
\hline \multirow[t]{2}{*}{ LSD at 0.05 level } & 0.11 & NS & 0.23 & $\mathbf{0 . 3 3}$ & 0.31 & 0.74 & 0.03 & 0.23 \\
\hline & \multicolumn{8}{|c|}{ Effect of sulphur (kg/fed.) } \\
\hline $\mathbf{0}$ & 2.52 & 2.51 & 1.24 & 1.18 & 3.76 & 3.70 & 2.17 & 2.28 \\
\hline 100 & 2.65 & 2.71 & 1.52 & 1.37 & 4.18 & 4.09 & 2.50 & 2.60 \\
\hline 200 & 2.74 & 2.82 & 1.57 & 1.53 & 4.31 & 4.35 & 2.81 & 2.76 \\
\hline LSD at 0.05 level & 0.12 & 0.14 & 0.13 & 0.14 & 0.18 & 0.17 & NS & 0.19 \\
\hline
\end{tabular}

FYM: Farmyard manure, $1^{\text {st }}$ and $2^{\text {nd }}:$ First and second seasons, respectively 
Results are in harmony with those obtained by Mahmoud (1999) on onion and Mansour (2006) on garlic who found that elemental sulphur recorded maximum concentration of chlorophyll $a, b$, total $(a+b)$ as well as carotenoids in leaf tissues of garlic.

\subsection{Effect of interaction between FYM and $S$}

The obtained results in Table 7 indicate that the interaction between FYM at $30 \mathrm{~m}^{3} / \mathrm{fed}$. and $\mathrm{S}$ at 100 or $200 \mathrm{~kg} / \mathrm{fed}$. recorded the maximum values of chlorophyll $\mathrm{a}, \mathrm{b}$ and total $(\mathrm{a}+\mathrm{b})$ in both seasons as well as carotenoides in the 2 nd season.

\section{3. $\mathbf{N}, \mathbf{P}$ and $K$ contents and uptake}

\subsection{Effect of FYM}

The obtained results in Tables 8 and 9 show that fertilization of garlic plants with FYM at $30 \mathrm{~m}^{3} /$ fed significantly increased $\mathrm{N}$ and $\mathrm{P}$ contents in bulb and leaves as well as N,P and K uptakes by roots, bulb and leaves and total uptake of N,P and K by plant, followed by FYM at 20 $\mathrm{m}^{3}$ /fed. with no significant differences between 20 and $30 \mathrm{~m}^{3} \mathrm{FYM} / \mathrm{fed}$. with respect to $\mathrm{P}$ content in leaves. FYM contains microorganisms as Azotobacter, Azospirillum,...etc. which fix $\mathrm{N}$ and release phytohormones as GA, IAA,CYT, etc. necessary for stimulating plant growth and dry matter content. These observations may indicate that micro-organisms have the ability to supply growing plants with $\mathrm{N}, \mathrm{P}, \mathrm{K}$ and photohormones which in turn may increase $\mathrm{N}, \mathrm{P}$ and $\mathrm{K}$ concentrations in soil solution and their uptakes by plant (Reynders and Vlassak,1982).

Results agree with Fayed (1998) and El-Mansi et al., (2004a) on garlic. They found that addition of $45 \mathrm{~m}^{3} \mathrm{FYM} / \mathrm{fed}$ recorded maximum values of total N, P and K uptake / plant.

\subsection{Effect of sulphur}

It is clear, from data in Tables 8 and 9 that $S$ at $200 \mathrm{~kg} / \mathrm{fed}$. increased $\mathrm{N}$ and $\mathrm{P}$ contents in roots and bulbs, the contents of $\mathrm{N}, \mathrm{P}$ and $\mathrm{K}$ in leaves, the uptakes of $\mathrm{N}, \mathrm{P}$ and $\mathrm{K}$ by roots, bulb and leaves as well as their total uptake by plant, followed by $\mathrm{S}$ at $100 \mathrm{~kg} / \mathrm{fed}$. with no significant differences between 100 and $200 \mathrm{~kg} / \mathrm{fed}$. with respect to $\mathrm{N}$ and $\mathrm{P}$ contents in roots and N,P and $\mathrm{K}$ contents in leaves. The increments in nutrients uptake under sulphur treatments might be resulted from sulphur role in adjusting sandy soil $\mathrm{pH}$ which increased nutrients availability and in turn reflected as more nutrients uptake and plant growth (Mehana, 1994). 
Table 7: Effect of the interaction between farmyard manure and sulphur quantity on leaf pigments of garlic leaves at 135 days after planting during 2008/2009 and 2009/2010 seasons under sandy soil conditions

\begin{tabular}{|c|c|c|c|c|c|c|c|c|c|}
\hline \multirow{2}{*}{\multicolumn{2}{|c|}{ Treatments }} & \multicolumn{8}{|c|}{ Leaf pigments ( $\mathrm{mg} / \mathrm{gm} \mathrm{DW})$} \\
\hline & & \multicolumn{2}{|c|}{$\begin{array}{l}\text { Chlorophyll } \\
\text { (a) }\end{array}$} & \multicolumn{2}{|c|}{$\begin{array}{l}\text { Chlorophyll } \\
\text { (b) }\end{array}$} & \multicolumn{2}{|c|}{$\begin{array}{c}\text { Total chlorophyll } \\
(\mathbf{a}+\mathbf{b})\end{array}$} & \multicolumn{2}{|c|}{ Carotenoides } \\
\hline FYM & Suphur & $\mathbf{1}^{\text {st }}$ & $2^{\text {nd }}$ & $1^{\text {st }}$ & $2^{\text {nd }}$ & $1^{\text {st }}$ & $2^{\text {nd }}$ & $1^{\text {st }}$ & $2^{\text {nd }}$ \\
\hline \multirow{3}{*}{10} & $\mathbf{0}$ & 2.29 & 2.19 & 1.08 & 1.13 & 3.38 & 3.32 & 2.14 & 2.09 \\
\hline & 100 & 2.46 & 2.54 & 1.19 & 1.23 & 3.65 & 3.78 & 2.31 & 2.35 \\
\hline & 200 & 2.46 & 2.57 & 1.25 & 1.36 & 3.71 & 3.93 & 2.42 & 2.46 \\
\hline \multirow[t]{3}{*}{20} & $\mathbf{0}$ & 2.50 & 2.48 & 1.24 & 1.16 & 3.74 & 3.65 & 2.06 & 2.28 \\
\hline & 100 & 2.52 & 2.76 & 1.49 & 1.29 & 4.02 & 4.05 & 2.54 & 2.61 \\
\hline & 200 & 2.64 & 2.87 & 1.58 & 1.34 & 4.23 & 4.21 & 2.88 & 2.65 \\
\hline \multirow[t]{3}{*}{30} & 0 & 2.78 & 2.87 & 1.40 & 1.27 & 4.18 & 4.14 & 2.32 & 2.47 \\
\hline & 100 & 2.98 & 2.84 & 1.87 & 1.60 & 4.86 & 4.44 & 2.67 & 2.85 \\
\hline & 200 & 3.13 & 3.02 & 1.87 & 1.88 & 5.00 & 4.91 & 3.13 & 3.17 \\
\hline \multicolumn{2}{|c|}{$\begin{array}{c}\text { LSD at } 0.05 \\
\text { level }\end{array}$} & 0.24 & 0.25 & 0.23 & 0.25 & 0.30 & 0.30 & NS & 0.32 \\
\hline
\end{tabular}

Farmyard manure, $1^{\text {st }}$ and $2^{\text {nd }}:$ First and second seasons, respectively

Table 8: Effect of farmyard manure and sulphur quantity on minerals content of different garlic organs at 135 days after planting during 2009/2010 season under sandy soil conditions

\begin{tabular}{|c|c|c|c|c|c|c|c|c|c|}
\hline \multirow[t]{3}{*}{ Treatments } & \multicolumn{9}{|c|}{ Minerals content (\%) } \\
\hline & \multicolumn{3}{|c|}{ Root } & \multicolumn{3}{|c|}{ Bulb } & \multicolumn{3}{|c|}{ Leaves } \\
\hline & $\mathbf{N}$ & $\mathbf{P}$ & $\mathbf{K}$ & $\mathbf{N}$ & $\mathbf{P}$ & $\mathbf{K}$ & $\mathbf{N}$ & $\mathbf{P}$ & $\mathbf{K}$ \\
\hline & \multicolumn{9}{|c|}{ Effect of FYM $\left(m^{3} /\right.$ fed. $)$} \\
\hline 10 & 1.39 & 0.275 & 1.26 & 1.92 & 0.399 & 1.80 & 3.12 & 0.331 & 2.83 \\
\hline 20 & 1.57 & 0.291 & 1.25 & 2.32 & 0.485 & 1.81 & 3.49 & 0.361 & 3.00 \\
\hline 30 & 1.58 & 0.285 & 1.34 & 2.18 & 0.472 & 1.96 & 3.67 & 0.355 & 2.97 \\
\hline $\begin{array}{c}\text { LSD at } 0.05 \\
\text { level }\end{array}$ & NS & NS & $\mathbf{N S}$ & 0.07 & 0.011 & NS & 0.13 & 0.011 & NS \\
\hline & \multicolumn{9}{|c|}{ Effect of sulphur (kg/fed.) } \\
\hline $\mathbf{0}$ & 1.34 & 0.272 & 1.28 & 1.73 & 0.438 & 1.79 & 3.21 & 0.329 & 2.84 \\
\hline 100 & 1.57 & 0.285 & 1.28 & 2.11 & 0.449 & 1.89 & 3.55 & 0.357 & 2.92 \\
\hline 200 & 1.63 & 0.294 & 1.29 & 2.58 & 0.468 & 1.89 & 3.52 & 0.361 & 3.03 \\
\hline $\begin{array}{c}\text { LSD at } 0.05 \\
\text { level }\end{array}$ & 0.09 & 0.010 & NS & 0.08 & 0.012 & NS & 0.05 & 0.009 & 0.14 \\
\hline
\end{tabular}

FYM: Farmyard manure 
Similar results were agree with those obtained by Singh et al. (1995) and Abd El-Hameed (1997), Fayed (1998) and El-Morsy (2005) , Mansour (2006) and Abou El-Khair (2010) on garlic.

\subsection{Effect of the interaction between FYM and $S$}

The obtained results in Tables 10 and 11 illustrate that, in general, the interaction between FYM at $30 \mathrm{~m}^{3} / \mathrm{fed}$. and $\mathrm{S}$ at $200 \mathrm{~kg} / \mathrm{fed}$. increased $\mathrm{P}$ content in roots, $\mathrm{N}$ and $\mathrm{P}$ in bulb and N,P and $\mathrm{K}$ contents in leaves, the uptakes of N,P and $\mathrm{K}$ by roots, bulb and leaves and N,P and $\mathrm{K}$ total uptake by plant, followed by the interactions between FYM at $30 \mathrm{~m}^{3} / \mathrm{fed}$ and $\mathrm{S}$ at $100 \mathrm{~kg} / \mathrm{fed}$. and the interaction between FYM at $20 \mathrm{~m}^{3} / \mathrm{fed}$. and $\mathrm{S}$ at 100 $\mathrm{kg} / \mathrm{fed}$ as well as the interaction between FYM at $20 \mathrm{~m}^{3} / \mathrm{fed}$. and $\mathrm{S}$ at 200 $\mathrm{kg} / \mathrm{fed}$.

\section{Yield and its components}

\subsection{Effect of FYM}

Fertilization of garlic plants with FYM at $30 \mathrm{~m}^{3} / \mathrm{fed}$. significantly increased yields of grades 1, 2 and 3, exportable, marketable and total yield/fed as well as average bulb weight, followed by FYM at $20 \mathrm{~m}^{3} / \mathrm{fed}$., whereas FYM at $10 \mathrm{~m}^{3} / \mathrm{fed}$. significantly increased yield of grade 4 in both seasons (Table 12).

Obtained results can be explained in the light of the facts that using FYM increases organic matter, availability of nutrients, nitrogen fixation, rizosphere microorganisms that release phyotohrmones and substances which led to increase growth and dry matter accumulation and this in turn might increase average bulb weight, hence increase the total yield.

These results are agree with those reported with Fayed (1998), Zhang et al. (1998), El-Mansi et al. (2004b) and El-Hifny (2010). They found that application of FYM to garlic plants were increased yield and its components.

\subsection{Effect of sulphur}

Fertilization of garlic plants with $\mathrm{S}$ at $200 \mathrm{~kg} / \mathrm{fed}$. significantly increased yields of grades 1, 2 and 3, exportable, marketable and total yield/fed. as well as average bulb weight, followed by $S$ at $100 \mathrm{~kg} / \mathrm{fed}$. whereas the control (without $S$ ) increased yield of grade 4 in both seasons (Table 12).

The influence of $S$ on the yield of garlic could be attributed to the important role of sulphur in protein and some hormones formation in plant, 
also sulphur is necessary for enzymatic action, chlorophyll formation, synthesis of certain amino acids and vitamins and consequently it helps to have a good vegetative growth leading to get high yield (Tisdale and Nelson, 1985).

These results are in accordance with these obtained by Abd ElHameed (1997) and Mee et al. (1997), El-Morsy (2005) and Farooqui et al. (2009). Application of $200 \mathrm{~kg} \mathrm{S/fed.} \mathrm{as} 50 \%$ at soil preparation + $50 \%$ at 30 days after planting gave the highest values of bulb yield of grades 1, 2, exportable, marketable, and total yield /fed., as well as, average bulb weight (Abou El-Khair ,2010).

\subsection{Effect of the interaction between FYM and $S$}

The interaction between FYM at $30 \mathrm{~m}^{3} / \mathrm{fed}$. and $\mathrm{S}$ at $200 \mathrm{~kg} / \mathrm{fed}$. significantly increased yields of grades 1, 2 and 3, exportable, marketable and total yield/fed as well as average bulb weight, followed by the interaction between FYM at $30 \mathrm{~m}^{3} / \mathrm{fed}$. and $\mathrm{S}$ at $100 \mathrm{~kg} / \mathrm{fed}$. in both seasons. The interaction between FYM and $\mathrm{S}$ at different rates had no significant effect on yield of grade 4 (Table 13).

These results are in harmony with those obtained with Khalaf and Taha (1988) on garlic.

\section{Sulphur use efficiency (SUE)}

Presented data in Table 14, show that FYM at $20 \mathrm{~m}^{3} / \mathrm{fed}$. recorded maximum value of SUE as $\mathrm{kg}$ bulb/ $\mathrm{kg} \mathrm{S}$ (7.98 and $4.32 \mathrm{~kg}$ bulb/1 $\mathrm{kg} \mathrm{S}$ ) in the $1^{\text {st }}$ and $2^{\text {nd }}$ seasons, respectively.

Also, from the same Table, data reflect that $S$ at $100 \mathrm{~kg} / \mathrm{fed}$. gave the highest values of SUE as $\mathrm{kg}$ bulb/kg S (10.10 and $6.17 \mathrm{~kg}$ bulb/kg S in the $1^{\text {st }}$ and $2^{\text {nd }}$ seasons, respectively. The interaction between FYM at $20 \mathrm{~m}^{3} / \mathrm{fed}$ and $\mathrm{S}$ at $100 \mathrm{~kg} / \mathrm{fed}$. was the best interaction treatments for enhancing SUE (14.19 and $6.69 \mathrm{~kg}$ bulb/1 $\mathrm{kg} \mathrm{S}$ in the $1^{\text {st }}$ and $2^{\text {nd }}$ seasons, respectively) followed by the interaction between FYM at $30 \mathrm{~m} 3 / \mathrm{fed}$ and $\mathrm{S}$ at $100 \mathrm{Kg} / \mathrm{fed}$. Under FYM at $10 \mathrm{~m}^{3} / \mathrm{fed}$. , SUE increased with increasing S., whereas under 20 and $30 \mathrm{~m}^{3} /$ fed. SUE decreased with increasing $S$ up to $200 \mathrm{~kg} / \mathrm{fed}$.

These results are in harmony with those obtained by Abou ElKhair (2010) on garlic. 
Table 14. Effect of farmyard manure and sulphur quantity and their interaction on sulphur use efficiency (SUE) of garlic during 2008/2009 and 2009-2010 seasons under sandy soil conditions

\begin{tabular}{|c|c|c|c|c|c|c|c|c|}
\hline \multirow{3}{*}{$\begin{array}{c}\text { FYM } \\
\left(\mathbf{m}^{3} / \text { fed. }\right)\end{array}$} & \multicolumn{8}{|c|}{ Sulphur ( kg/fed) } \\
\hline & \multicolumn{2}{|c|}{$\mathbf{0}$} & \multicolumn{2}{|c|}{100} & \multicolumn{2}{|c|}{200} & \multicolumn{2}{|c|}{ Average } \\
\hline & $1^{\text {st }}$ & $2^{\text {nd }}$ & $1^{\text {st }}$ & $2^{\text {nd }}$ & $1^{\text {st }}$ & $2^{\text {nd }}$ & $1^{\text {st }}$ & $2^{\text {nd }}$ \\
\hline 10 & 0.0 & $0 . .0$ & 4.07 & 6.06 & 7.75 & 6.95 & 3.94 & 4.34 \\
\hline 20 & 0.0 & 0.0 & 14.19 & 6.69 & 9.74 & 6.28 & 7.98 & 4.32 \\
\hline 30 & 0.0 & 0.0 & 12.05 & 5.76 & 9.76 & 4.66 & 7.27 & 3.47 \\
\hline Average & 0.0 & 0.0 & 10.10 & 6.17 & 9.08 & 5.96 & -- & -- \\
\hline
\end{tabular}

Conclusively, from the foregoing results of this experiment, it could be concluded that, the interaction between FYM at the rate of $30 \mathrm{~m}^{3} / \mathrm{fed}$. and 200 $\mathrm{kg}$ S/fed. significantly increased total dry weight / plant, uptakes of N,P and $K$ by roots, bulb and leaves as well as total uptakes of N,P and $K$ by plant, yields of grades 1,2 and 3, exportable, marketable and total yield/fed., as well as, average bulb weight, whereas the interaction between FYM at $20 \mathrm{~m} 3 /$ fed and $S$ at $100 \mathrm{Kg} /$ fed increased sulphur use efficiency.

\section{REFERENCES}

Abd El-Hameed, A.M. (1997). Influence of sulphur application and some micronutrients on growth and productivity of garlic (Allium sativum, L.). Minufiya Journal of Agriculture Research, 22(2):445-458.

Abdel-Moez, M. R., A. L., Saleh and Sh. A H.; Wanas (1999). Influence of some organic composts on yield; nutrients uptake and consumptive use of

fennel and coriander plants and some soil physical properties. Journal of Agriculture Sci., Mansoura University, 24 (10): 6237-6253.

Abou El-Khair, E.E.(2010). Effect of sulphur quantity a nd time of application on yield, bulb quality and storability of garlic under drip irrigation system in sandy soil. J. Product. \& Develop., 15(1): 105- 122.

Ali, A. H., M. M. Abdel -Mouty, and A. M. Shaheen (2001). Effect of bionitrogen ,organic and inorganic fertilizers on the productivity of garlic (Allium sativum L.)plants. Egyptian J. Appl. Sci., 16 (3): 173-188. 
Bharathi C. and S. Poongothai (2008). Direct and residual effect of sulphur on growth, nutrient uptake, yield and its use efficiency in maize and subsequent greengram. Res. J. Agric. and Biol. Sci., 4(5): 368-372.

Bloem, E.S., I. Hanek and E. Schnug. (2004). Influence of nitrogen and sulphur fertilization on the alliin content of onions and garlic. Journal of Plant Nutr., 27 (10): 1827-1839.

Bremner, J. M., and C. S. Mulvaney (1982). Total Nitrogen. In: Page, A. L., R. H. Miller, and D. R. Keeney (Eds). Methods of Soil Analysis. Part 2, Amer. Soc. Agron. Madison, W. I. USA. pp. 595- 624.

Brown, P.D. and M.J. Morra (1997). Control of soil-born plant pests using glucosinolate containing plants. Adv. Agron., 61:161-231.

Cooke, G.W. (1972). Fertilization for maximum yield. Richard Clay (The chaucer press) LTD. Bungary. Suffok. Great Britian pp. 457.

El-Hifny I, M. (2010). Response of garlic (Allium sativum L.) to some sources of organic fertilizers under north sinai conditions. Research Journal of Agric. \& Biol. Sci., 6(6): 928-936.

El-Mansi, A.A., A. Bardisi, A. N. Fayad, and E. E. Abou- El-Khair ( 2004 a). Effect of water quantity and farmyard manure on garlic under sandy soil conditions. 1. Dry weight and plant chemical composition. Zagazig Journal of Agriculture Research, 31 (2) :253-277.

El-Mansi, A.A., A. Bardisi, A. N. Fayad, and E. E. Abou- El-Khair. (2004 b). Effect of water quantity and farmyard manure on garlic under sandy soil conditions. 2. Yield and its components, water use efficiency and bulb quality. Zagazig . J. Agric. Res., 31 (4A) :1385-1408.

El-Morsy, A.H.A. (2005). Effect of sulphur levels and foliar application of certain micronutrients on garlic (Allium sativum L.). 6th Arab. Conf. Horti., Ismailia, Egypt 454-464.

Farooqui, M.A., I.S. Naruka, S.S. Rathore, P.P. Singh and R.P.S. Shaktawat. (2009). Effect of nitrogen and sulphur levels on growth and yield of garlic (Allium sativum L.). Asian. J. Food Agro-Industry, Special Issue, $\mathbf{S}$ 18-23.

Farrag, Amal M., and A. E. Hussein (2000). Response of onion plants to sources and rates of organic fertilizers . J. Agric. Sci., Mansoura Univ., 25 (7) : 4497-4514.

Fayed, R. M. (1998). Effect of chicken manure and sulphur mixture with NPK fertilizers on growth, yield and NPK contents of garlic and pea plants. $J$. Agric. Mansoura Univ, Mansoura, Egypt, 23 (5) : 2305-2313.

Hseih, C. F., and K. N. Hsu (1993). An experiment on the organic farming of sweet corn and vegetable soybeans. Bulletin of Taichung District Agricultural Improvement Station, 39:29-39. 
Jackson, M. L. (1970). Soil Chemical Analysis. Prentic Hall, Englewood Ceiffs, N. J.

Jaggi, R.C. (2004). Effect of sulphur levels and sources on composition and yield of onion (Allium cepa). Indian J. Agric. Sci. , 74 (4): 219-220.

Khalaf, Sohair M., and E .M. Taha (1988). Response of garlic plants grown on calcareous soil to organic manuring and sulphur application. Annual of Agric. Sci., Fac. Agric., Ain Shams Univ., Egypt, 33 (2): 1219-1232.

Losak T. and B. Winiowska-Kielian (2006). Fertilization of garlic (Allium sativum L.) with nitrogen and sulphur. Annals Universitatis Mariaecurie - Sklodowska, Lublin - Polonia

Mahmoud, Asmaa R. (1999). Effect of some agricultural treatments on productivity and quality of onion. Ph. D. Thesis, Fac. Agric., Ain Shams Univ., Cairo, Egypt.

Mansour, F.Y.O. (2006). Physiological studies on garlic(Allium sativum, L.). M. Sc. Thesis, Faculty of Agriculture, Minufia University, Egypt.

Marschner, H. (1995). Mineral Nutrition of Higher Plants. 2nd (ed.), Academic Press Limited, Text Book.

Mee, H. P., K. JeongOk, K. Uigum, K. HangWon, and P. KyeongBea (1997). Effect of sulphur and potassium sulphate application on yield and volatile compounds by garlic (Allium sativum L.) varieties. RDA J. AgroEnviron. Sci., 39 (2): 35-39. (C.F. CAB-International Abst. Computer Res.).

Mehana, T.A. (1994). Microbiological properties and nutrient availability in a salt-affected calcareous soil as influenced by certain amendments under leaching conditions. Bull. Suez Canal Univ., Appl. Sci., 3: 384-402.

Ministry of Economy , Egypt (1963). To control exported garlic. Ministerial order No.652.

Olsen, S. R., and L. E. Sommers (1982). Phosphorus. In: Page. A. L., R. H. Miller, and D. R.Keeney (Eds). Methods of Soil Analysis .Part 2 Amer. Soc. Agron. Madison, W. I. USA. pp. 403-430.

Reynders, L., and K. Vlassak (1982). Use of Azospirillum brasilense as biofertilizer in intensive wheat cropping, Plant and Soil, 66: 217-223.

Seno, S., G. G. Saliba, F. J. de Paula, P. S. Koga, and F. J. De Paula (1996). Effect of phosphrous and chicken manure on the garlic culture (Allium sativum L.) Cientifica , Jaboticabal, 24 (1):127-133 .(C.F.CAB, Abstr.1998-1999/04).

Shafeek, M.R., Faten S. Abd El-Al and Mona M. Abd El Mouty (2003). The productivity of garlic plant as affected by the addition of nitrogen fertilizer in the form of organic and /or inorganic. J. Agric. Sci., Mansoura Univ., 28 (1): 7395-7403. 
Singh, V., A. Singh, V.S. Mehta, V. Singh and A. Singh (1995). Effect of sulphur sources and levels on yield and uptake of nutrients by garlic. Fertilizer News, 40(8):47-49. ( C.F. CAB Abstr. 1996-1998/07).

Snedecor, G.W., and W.G.Cochran (1980). Statistical Methods.7th ed. Iowa State Univ., Press, Ames., Iowa, U.S.A.

Tisdale, S.L. and W.L. Nelson (1985). Soil Fertility and Fertilizers, 3rd ed. Macmillan Publishing Co. Inc., New York and Collico-Macmillan Publishers, London.

Wettestein, D. (1957). Chlorophyll. Lethale under submikroskopische formwechsel der plastiden. Exptl. Cell Reso., 12:427-506.

Zhang, X., H. Zhu, and C. Sun (1998). Study on balance fertilization and NPK nutrient absorption of garlic. Soils and fertilizers (Beijing) 1: 10-13. (C.F.Hort.Abstr. 69, 3021). 


\title{
تأثير السماد البلدى والكبريث على النمو والإنتاجية وكفاعة استخدام

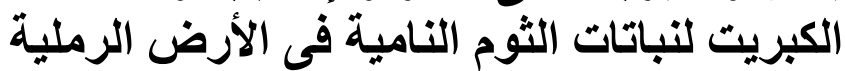

\author{
عبد الله برديسى ، هانى السيد محمد اسماعيل ، داليا احمد سامى نوار

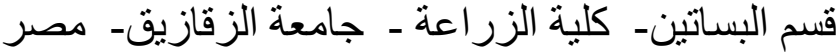

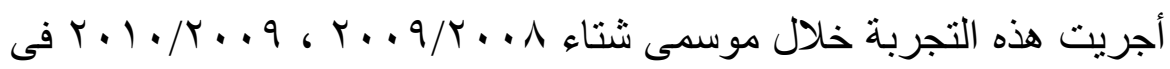

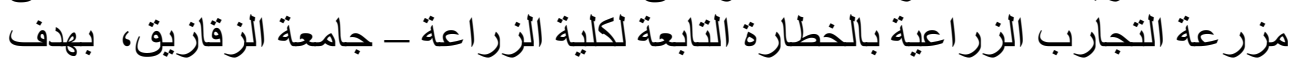

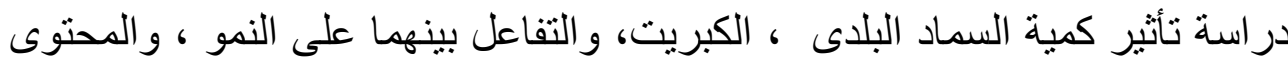
الكيماوى ، و المحصول ومكوناته بجانب كفاءة استخدام نباتات الثوم للكبريت تحت

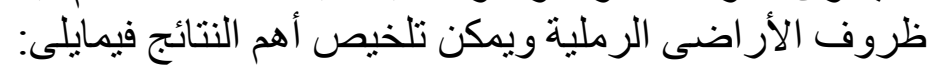

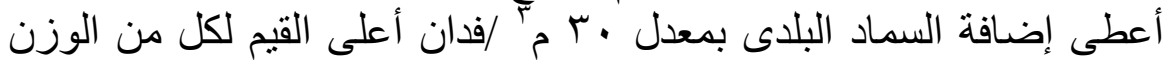

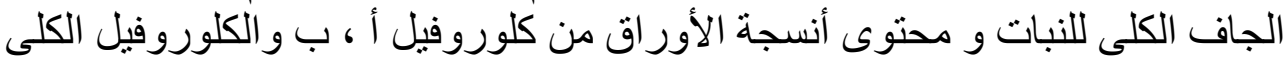

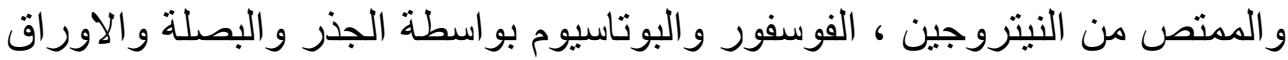

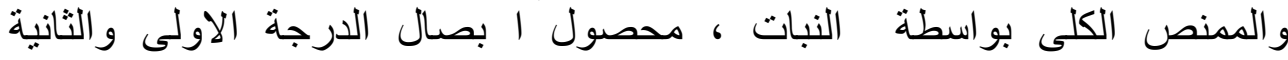
و المحصول القابل للتصدير و المحصول القابل للتسوق و الكلى ومتوسط وزن البهل البصلة .

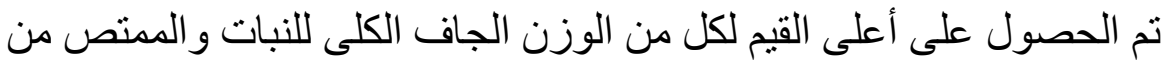

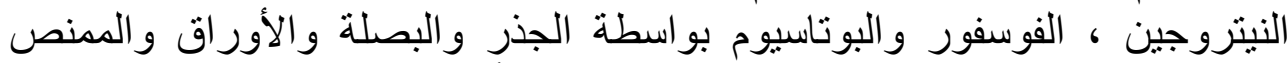

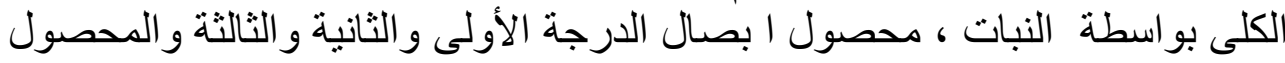

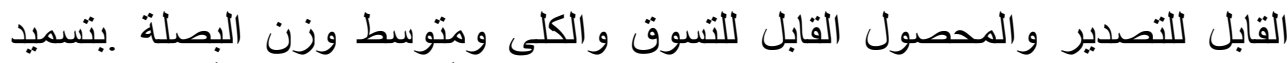

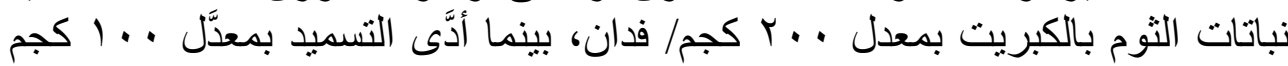

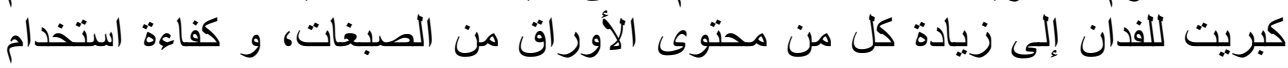

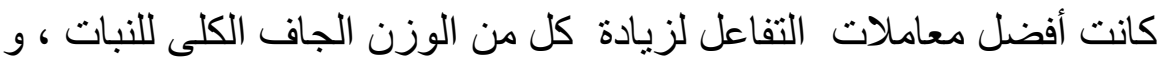
النباتات للكبريت.

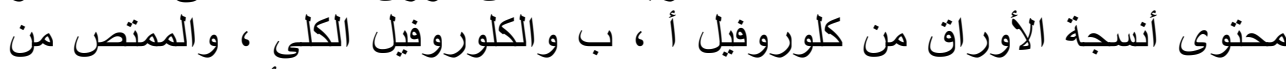

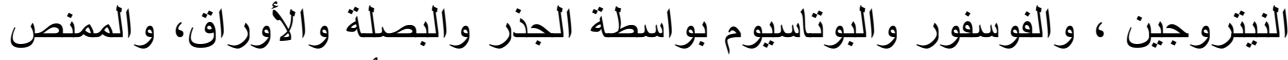

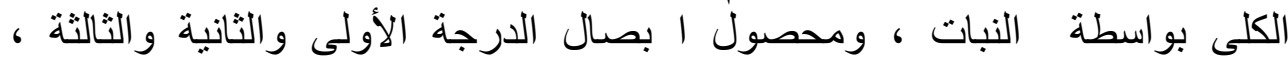

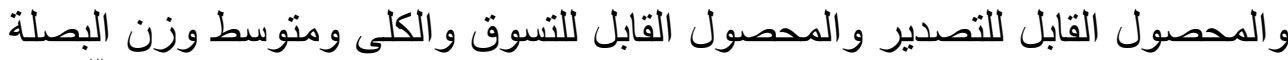

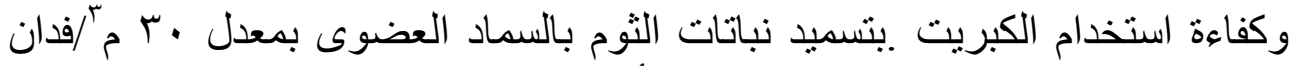

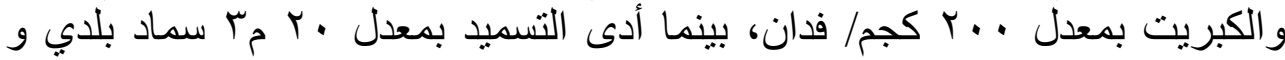

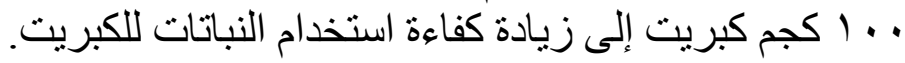


